\title{
JUAL BELI APARTEMEN KEPADA PIHAK KETIGA ATAS DASAR PERJANJIAN PENGIKATAN JUAL BELI (PPJB)
}

\author{
Siti Nurul Intan Sari Dalimunthe \\ sinuinsada@yahoo.com \\ Fakultas Hukum, Universitas Pembangunan Nasional "Veteran" Jakarta \\ Wardani Rizkianti \\ rizkianti88@gmail.com \\ Fakultas Hukum, Universitas Pembangunan Nasional "Veteran" Jakarta
}

\begin{abstract}
ABSTRAK
Pelaksanaan jual beli apartemen banyak dilakukan dengan cara memesan terlebih dahulu unit apartemen yang akan dibeli, kemudian dituangkan dalam Perikatan Perjanjian Jual Beli (PPJB) sebagai pengikatan sementara dengan ditandai pemberian uang muka sebagai tanda jadi, untuk mengamankan kepentingan developer dan calon pembeli. Bahkan tidak sedikit, PPJB yang dibuat sudah dilunasi oleh pembeli. Pada prakteknya, jarak antara PPJB sampai AJB yang terlalu lama, dikarenakan apartemen belum selesai ataupun sertifikat yang belum pecah, membuat pembeli yang membutuhkan uang menjual kembali kepada pihak ketiga atas dasar PPJB yang dimiliki. Rumusan masalah penelitian ini: (1) Apakah Perjanjian Pengikatan Jual Beli (PPJB) Apartemen telah mengalihkan Hak Milik atas Satuan Rumah Susun (HMSRS) ? dan (2) Bagaimana bentuk pengalihan hak yang dilakukan oleh pembeli apartemen kepada pihak ketiga atas dasar PPJB ?. Penelitian ini adalah penelitian hukum normatif, dengan data sekunder dan pendekatan undang-undang (statute approach). Berdasarkan SEMA 4/2016, Bagian B Rumusan Hukum Perdata, Perdata Umum angka 7, PPJB yang terjadi dimana pembeli telah membayar secara lunas serta telah menguasai objek PPJB, dan dilakukan dengan itikad baik, maka secara hukum telah terjadi peralihan hak dan bentuk pengalihan hak yang dilakukan oleh pembeli apartemen kepada pihak ketiga atas dasar PPJB dapat dilakukan melalui Perjanjian Pengalihan Hak.
\end{abstract}

Kata Kunci : Jual Beli, Apartemen, PPJB

\section{ABSTRACT}

The sales and purchase of apartments is mostly done by ordering the apartment units to be purchased in advance, then included in a transfer agreement (PPJB) with advance payment as a temporary binding mark to secure the interests of developers and prospective buyers. In fact, while a PPJB is made, most customer completes the payment instead. In practice, the time range between the issuance of PPJB Agreement and Deed of Sale and Purchase is too long, because the apartment has not been completed or its certificate of ownership has not finally issued. As the result, the buyer who sell this asset to third parties on the basis of the Purchase Binding Agreement owned. The research problems are: (1) Has the PPJB transferred the right of the apartment unit ownership? and (2) What is the 
form of transfer of rights carried out by the buyer of the apartment unit to a third party on the basis of the PPJB? This research is a normative legal research in which secondary data are used and statute approach is employed. Based on SEMA 4/2016, Part B Civil Law Formulation, Civil Code number 7, PPJB that occurs in a case of the buyer has paid in full and has mastered the object of the Sale and Purchase Agreement, and is done in good faith, then legally there has been a transfer of rights and the form of transfer of rights carried out by the apartment buyer to a third party on the basis of the Sale and Purchase Agreement can be done through the Transfer of Rights Agreement.

Keywords: Sale and Purchase, Apartments, PPJB

\section{PENDAHULUAN}

Kebutuhan manusia, tidak terlepas dari kebutuhan primer, sekunder dan tersier. Kebutuhan primer adalah kebutuhan yang harus dipenuhi oleh manusia untuk hidup, meliputi pangan, sandang dan papan. Perumahan dan pemukiman (papan) merupakan salah satu kebutuhan primer manusia yang harus dipenuhi. Dengan semakin bertambahnya jumlah penduduk dan jumlah lahan yang terbatas, maka pemenuhan kebutuhan pemukiman di perkotaan banyak dilakukan dengan pembangunan secara vertikal, yaitu melalui pembangunan rumah susun atau apartemen. Pembangunan apartemen di kota-kota besar pada umumnya banyak kita jumpai untuk mengatasi keterbatasan lahan yang sangat terbatas seiring dengan pertambahan penduduk yang semakin meningkat.

Pembangunan rumah susun umumnya ditargetkan untuk masyarakat menengah ke bawah, sedangkan pembangunan apartemen ditargetkan untuk masyarakat menengah ke atas. Pesatnya pembangunan apartemen di kota-kota besar seperti Jakarta, didukung dengan daya beli masyarakat yang tinggi, hal ini dikarenakan kondisi sosial dan ekonomi penduduk yang cukup beragam namun didominasi oleh penduduk kalangan menengah keatas dan adanya gaya hidup masyarakat di kota-kota besar yang lebih memilih hunian yang praktis dengan fasilitas yang memadai.

Tingginya kebutuhan masyarakat di kota besar akan pemenuhan kebutuhan pemukiman yang vertikal yaitu apartemen, membuat banyaknya investor yang tertarik untuk menjalankan bisnis properti apartemen. Hal ini terlihat dari iklan properti apartemen yang ditawarkan di mal-mal, selain itu iklan apartemen di media lainnya seperti media cetak, televisi, brosur dan lain-lain yang 
sangat gencar dilakukan oleh pihak developer secara besar-besaran. Namun penawaran apartemen dari pihak developer, harus dicermati dengan hati-hati oleh pihak pembeli. Karena tidak jarang, penawaran apartemen yang dilakukan oleh pihak developer, dilakukan pada saat apartemen masih dalam tahap perencanaan (belum ada bangunan apatemen).

Pelaksanaan jual beli apartemen banyak dilakukan dengan cara memesan terlebih dahulu atas unit yang akan dibeli, kemudian dituangkan dalam PPJB (Perjanjian Perikata Jual Beli) sebagai pengikatan sementara unit apartemen dengan pemberian uang muka sebagai tanda jadi, untuk mengamankan kepentingan developer dan calon pembeli apartemen. Bahkan tidak sedikit, PPJB yang dibuat sudah dilunasi harganya oleh pihak pembeli.

Pembayaran uang muka atau panjar maupun pembayaran lunas dalam PPJB, belum menyebabkan beralihnya Hak Milik atas Satuan Rumah Susun (apartemen) dari penjual kepada pembeli karena belum adanya Akta Jual Beli (AJB) yang dibuat oleh para pihak. Bahkan dengan adanya AJB pun belum menyebabkan perpindahan hak milik. Adapun hak milik baru berpindah dengan dilakukannya penyerahan (levering). Dengan demikian penyerahan (levering) merupakan suatu perbuatan hukum guna memindahkan hak milik yang caranya tergantung benda yang dijual.

Menurut Pasal 616 KUH Perdata, penyerahan benda tidak bergerak (Apartemen) dilakukan melalui pengumuman akta yang bersangkutan dengan cara seperti ditentukan dalam Pasal 620 KUHPerdata, antara lain membukukannya dalam register. Dengan berlakunya Undang-Undang Nomor 5 Tahun 1960 tentang Peraturan Dasar Pokok-Pokok Agraria (UUPA), maka pendaftaran hak atas tanah dan hak milik atas Satuan Rumah Susun, peralihan haknya dilakukan menurut ketentuan Pasal 19 UUPA dan peraturan pelaksananya, karena bukti kepemilikan hak atas suatu bidang tanah maupun hak milik atas Satuan Rumah Susun dibuktikan dengan adanya sertifikat tanah yang dalam hal ini berupa Serifikat Hak Milik Satuan Rumah Susun (SHMSRS).

Berdasarkan Pasal 37 ayat (1) Peraturan Pemerintah Nomor 24 Tahun 1997 tentang Pendaftaran Tanah (PP Pendaftaran Tanah) menyatakan bahwa : "Peralihan hak atas tanah dan hak milik atas satuan rumah susun melalui jual beli, 
tukar-menukar, hibah, pemasukan dalam perusahaan dan perbuatan hukum pemindahan hak lainnya, kecuali pemindahan hak melalui lelang hanya dapat didaftarkan jika dibuktikan dengan akta yang dibuat oleh PPAT (Pejabat Pembuat Akta Tanah) yang berwenang menurut ketentuan peraturan perundang-undangan yang berlaku". Melihat pada ketentuan tersebut, jual beli apartemen, haruslah dilakukan dengan Akta Jual Beli (AJB) yang dibuat dihadapan PPAT. Selain itu, harus adanya pendaftaran peralihan haknya di BPN (Badan Pertanahan Nasional) untuk balik nama.

Umumnya PPJB yang dilakukan dalam perikatan pembelian apartemen dilakukan karena unit apartemen belum jadi dan masih dalam tahap perencanaan. Selain itu, sertifikat hak miik atas satuan rumah susun yang belum pecah dari sertifikat induknya, juga menjadi faktor penghambat dilaksanakannya AJB. Lamanya tenggang waktu jual beli apartemen antara PPJB dan AJB, terkadang menimbulkan realita baru yang berkembang di masyarakat. Salah satunya adalah pengalihan unit apartemen tersebut kepada pihak ketiga oleh pembeli yang membutuhkan uang hanya dengan berdasarkan PPJB yang dipunyai oleh pihak pembeli, bahkan terkadang unit apartemenpun belum selesai dikerjakan dan belum pecah sertifikat induknya.

Oleh karena itu, peneliti tertarik untuk melakukan penelitian dengan rumusan permasalahan sebagai berikut :

1. Apakah Perjanjian Pengikatan Jual Beli (PPJB) Apartemen telah mengalihkan Hak Milik atas Satuan Rumah Susun (HMSRS) ?

2. Bagaimana bentuk pengalihan hak yang dilakukan oleh pembeli apartemen kepada pihak ketiga atas dasar PPJB ?

\section{METODE PENELITIAN}

\section{Jenis Penelitian}

Penelitian hukum dilihat dari tujuannya sendiri terdiri dari penelitian hukum normatif dan penelitian hukum sosiologis atau empiris. ${ }^{1}$ Jenis penelitian yang digunakan dalam penelitian ini merupakan penelitian hukum normatif. Menurut Soerjono Soekanto Penelitian yuridis normatif yaitu penelitian hukum 
yang dilakukan dengan cara meneliti bahan pustaka atau data sekunder sebagai bahan dasar untuk diteliti dengan cara mengadakan penelusuran terhadap peraturan-peraturan dan literatur-literatur yang berkaitan dengan permasalahan yang diteliti. ${ }^{2}$

\section{Sumber dan Jenis Data}

Bahan hukum yang dapat dijadikan sebagai objek dalam studi kepustakaan adalah data sekunder yang terdiri dari bahan hukum primer, sekunder dan tersier. Bahan hukum primer, yaitu bahan hukum yang bersifat mengikat yang terdiri dari

1) Kitab Undang-Undang Hukum Perdata (KUHPerdata)

2) Undang-Undang Nomor 20 Tahun 2011 tentang Rumah Susun.

3) Peraturan Pemerintah Nomor 24 Tahun 1997 Tentang Pendaftaran Tanah.

4) Peraturan Pemerintah Nomor 24 Tahun 2016 tentang Perubahan atas Peraturan Pemerintah Nomor 37 Tahun 1998 tentang Peraturan Jabatan Pejabat Pembuat Akta Tanah

5) Peraturan Menteri Pekerjaan Umum dan Perumahan Rakyat Nomor 11/PRT/M/2019 tentang Sistem Perjanjian Pendahuluan Jual Beli Rumah Bahan hukum sekunder, yaitu bahan hukum yang memberikan petunjuk serta penjelasan terhadap bahan hukum primer yang terdiri dari buku-buku literatur, makalah, artikel, hasil penelitian, dan karya ilmiah lainnya yang berhubungan dengan penelitian ini. Bahan hukum tersier, yaitu bahan hukum yang memberikan petunjuk dan penjelasan terhadap bahan hukum primer dan bahan hukum sekunder yang terdiri dari Kamus Umum Bahasa Indonesia.

\section{Alat Pengumpulan Data}

Dalam penelitian ini setiap kajian untuk pemecahan rumusan masalah pertama dan kedua dilakukan dengan studi kepustakaan. Mengumpulkan data yang terdapat dalam peraturan perundang-undangan, buku-buku, jurnal, dokumen-

${ }^{2}$ Ibid. 
dokumen hukum, makalah, majalah, surat kabar maupun data yang berasal dari karya ilmiah lainnya baik yang berasal dari media cetak maupun internet yang berkaitan dengan usulan penelitian ini.

\section{Analisis Data}

Analisis data dilakukan secara yuridis kualitatif. Data Penelitian dianalisis sesuai dengan permasalahan dan berdasarkan kerangka teori yang ada dan dilakukan secara logis dan sistematis. Analisis dilakukan dengan inventarisasi ketentuan-ketentuan dalam peraturan perundang-undangan yang menyangkut tentang peralihan jual beli apartemen atas dasar perjanjian pengalihan hak yang kemudia dikomparisikan dengan teori-teori yang berhubungan. Untuk lebih memudahkan analisis data, maka penulis menerapkan tahapan yakni, pertama, data penelitian diklasifikasikan sesuai dengan permasalahan yang ada; kedua, hasil klasifikasi data selanjutnya disistematiskan; ketiga, data yang tersistematisasi kemudian diolah dengan melakukan analisis, keempat, berdasarkan pengolahan data tersebut ditetapkanlah suatu kesimpulan dan saran.

\section{PEMBAHASAN}

\section{A. Aparetemen \& Hak Milik Atas Stuan Rumah Susun (HMSRS)}

Tempat tinggal bersusun memiliki istilah yang berbeda untuk masyarakat di Indonesia. Istilah rumah susun diperuntukkan untuk masyarakat bawah dengan sarana yang sederhana, sedangkan istilah apartemen digunakan untuk lapisan masyarakat menengah keatas dengan kualitas sarana prasarana yang mewah. Selain rumah susun dan apartemen, dikenal juga beragam istilah seperti flat, kondominium dan strata title. Meskipun terjadi perbedaan istilah, payung hukum apartemen, flat, kondominium dan strata title tetap merujuk pada Undang-Undang Nomor 20 Tahun 2011 tentang Rumah Susun.

Menurut Pasal 1 angka 1 Undang-Undang Rumah Susun:

"Rumah Susun adalah Bangunan gedung bertingkat yang dibangun dalam suatu lingkungan, yang terbagi dalam bagian-bagian yang distrukturkan secara fungsional dalam arah horizontal dan vertikal dan merupakan satuansatuan yang masing-masing dapat dimiliki dan dihuni secara terpisah, terutama untuk tempat hunian, yang dilengkapi dengan bagian bersama, benda bersama dan tanah bersama". 
Undang-Undang Rumah Susun mengklasifikasikan jenis kepemilikan atas rumah susun, yaitu pemilikan perorangan dan pemilikan bersama dalam satu kesatuan yang disebut Hak Milik Atas Satuan Rumah Susun yang pengertiannya adalah hak kepemilikan perseorangan atas satuan (unit) rumah susun, meliputi hak bersama atas bangunan, benda dan tanah. ${ }^{3}$

Konsep dasar yang melandasi Hak Milik Atas Satuan Rumah Susun berawal pada teori tentang kepemilikan atas suatu benda, bahwa benda atau bangunan dapat dimiliki oleh seseorang, dua orang, atau bahkan lebih yang dikenal dengan istilah pemilikan bersama. Pemilikan bersama atas suatu benda atau bangunan dibagi menjadi dua macam kepemilikan, yaitu kepemilikan bersama yang terikat dan kepemilikan bersama yang bebas. ${ }^{4}$ Pemilikan bersama yang terikat, yaitu adanya ikatan hukum yang terlebih dahulu ada diantara para pemilik benda bersama, misalnya pemilikan bersama yang terdapat di harta perkawinan. Sedangkan pemilikan bersama yang bebas adalah bahwa setiap para pemilik bersama tidak terdapat ikatan hukum terlebih dahulu, selain dari hak bersama menjadi pemilik dari suatu benda. Sehingga dalam hal ini adanya kehendak secara bersama-sama untuk menjadi pemilik atas suatu benda yang untuk digunakan secara bersama-sama. Bentuk kepemilikan bebas inilah yang dikenal dengan kondominium. ${ }^{5}$

Hak bersama tersebut dibagi menjadi tiga bagian, yaitu tanah bersama, benda bersama dan bagian bersama.

a. Tanah Bersama

Pasal 1 ayat 4 Undang-Undang Rumah Susun memberikan pengertian bahwa Tanah Bersama adalah Sebidang tanah yang digunakan atas dasar hak bersama secara tidak terpisah, yang di atasnya berdiri rumah susun dan ditetapkan batasnya dengan persyaratan izin bangunan.

b. Bagian Bersama

Pasal 1 ayat 5 Undang-Undang Rumah Susun memberikan pengertian bahwa Bagian Bersama adalah bagian rumah susun yang dimiliki secara

\footnotetext{
${ }^{3}$ Adrian Sutedi, Hukum Rumah Susun \& Apartemen, (Jakarta, Sinar Grafika, 2013) hal.
} 199.

\footnotetext{
${ }^{4}$ Ibid, hal.198.
}

${ }^{5}$ Ibid, hal 199. 
tidak terpisah untuk pemakaian bersama dalam satu kesatuan fungsi dengan satuan rumah susun. ${ }^{6}$ Bagian bersama ini merupakan struktur bagunan dari rumah susun seperti, pondasi, tangga, atap, ruang masuk, koridor, atap, jaringan listrik, dan lain-lain. Bagian-bagian bersama ini tidak dapat dimanfaatkan sendiri-sendiri oleh pemilik satuan rumah susun, tetapi pemanfaatannya dilakukan bersama-sama dengan penghuni rumah susun lainnya.

c. Benda Bersama

Pasal 1 ayat 6 Undang-Undang Rumah Susun memberikan pengertian bahwa Benda bersama adalah benda-benda yang bukan merupakan bagian rumah susun tetapi dimiliki bersama serta tidak terpisahkan untuk pemakaian bersama. Benda bersama yang melengkapi rumah susun agar berfungsi sebagaimana mestinya, ${ }^{7}$ misalnya generator listrik, perlengkapan parkir, fasilitas olahraga dan lain-lain.

Satuan rumah susun dapat dimiliki baik oleh perseorangan maupun badan hukum yang memenuhi persyaratan sebagai pemegang hak atas tanah, dan untuk mencapai tertib administrasi pertanahan serta memberikan kepastian dan perlindungan hukum kepada pemilik hak atas satuan rumah susun, maka sebagai tanda bukti kepemilikan pemerintah memberikan alat pembuktian yang kuat berupa sertipikat HMSRS (Hak Milik atas Satuan Rumah Susun) yang diterbitkan oleh Kantor Pertanahan Kabupaten/Kota setempat. ${ }^{8}$

Dari uraian di atas dapat disimpulkan bahwa Sistem kepemilikan atas rumah susun disebut sebagai Hak Milik Atas Satuan Rumah Susun (HMSRS). Sedangkan bukti kepemilikan HMRSR adalah Sertifikat Hak Milik Sarusun. Berdasarkan Pasal 1 angka 11 Undang-Undang Rumah Susun, Sertifikat Hak Milik Sarusun yang selanjutnya disebut SHM Sarusun adalah tanda bukti kepemilikan atas sarusun di atas tanah hak milik, hak guna bangunan atau hak pakai di atas tanah negara, serta hak guna bangunan atau hak pakai di atas tanah

\footnotetext{
${ }^{6}$ Indonesia, Pasal 1 ayat 4 Undang-Undang Nomor 20 Tahun 2011 tentang Rumah Susun.

${ }^{7}$ Arie S. Hutagalung, Kondominium dan Permasalahannya, (Jakarta : Badan Penerbit Fakultas Hukum Universitas Indonesia, 2007), hal.16.

${ }^{8}$ Pandam Nurwulan, "Aspek Hukum Transaksi Jual Beli Rumah Susun/Apartemen di Daerah Istimewa Yogyakarta Kaitannya dengan Peran Notaris-PPAT", Jurnal Hukum Ius Quia Iustum, Volume 22 Nomor 4, Oktober 2015, hal. 680-681
} 
hak pengelolaan. Apartemen yang akan dijual wajib memiliki izin-izin yang diperlukan seperti izin lokasi, bukti penguasaan dan pembayaran tanah, dan izin mendirikan bangunan.

\section{B. Perjanjian Pengikatan Jual Beli (PPJB) Apareteman}

Perjanjian pendahuluan jual beli apartemen dapat dilakukan sebelum bangunan apartemen selesai dibangun maupun sertifikat apartemen yang belum pecah. Berdasarkan Peraturan Menteri Pekerjaan Umum dan Perumahan Rakyat Nomor 11/PRT/M/2019 tentang Sistem Perjanjian Pendahuluan Jual Beli Rumah, yang juga memuat ketentuan tentang Rumah Susun (selanjutnya disebut PERMEN PUPR No.11/PRT/M/2019), pada Pasal 3 angka 2, pelaku pembangunan dapat melakukan pemasaran pembangunan rumah susun sebelum pembangunan dilaksanakan. Dalam prakteknya, satuan apartemen yang masih dalam tahap proses pembangunan dipasarkan melalui sistem pemesanan (indent). Pada saat pemesanan calon pembeli menandatangani surat pesanan yang disiapkan oleh perusahaan developer atau pengembang. Setelah penandatanganan surat pesanan tersebut, pemesan (calon pembeli) dan developer sudah harus menandatangani PPJB yang memuat penjelasan mengenai obyek yang akan diperjualbelikan.

Obyek yang akan diperjualbelikan oleh developer adalah hak milik atas satuan rumah susun (HMSRS), yang meliputi pula bagian bersama, benda bersama dan tanah bersama berikut fasilitasnya di lingkungan rumah susun tersebut sesuai perbandingan proporsional dari satuan rumah susun yang bersangkutan. ${ }^{9}$

PPJB biasanya dibuat sebagai kesepakatan awal agar kesepakatan jual beli dapat terlaksana di kemudian hari. Berdasarkan Pasal 1 angka 1 PERMEN PUPR No.11/PRT/M/2019, PPJB adalah rangkaian proses kesepakatan antara setiap orang dengan pelaku pembangunan dalam kegiatan pemasaran yang dituangkan

${ }^{9} \mathrm{https}: / /$ www.hukumonline.com/klinik/detail/ulasan/lt4c5ba2076b60d/ppjb-tentangrusunami/, PPJB Tentang Rusunami, diakses tanggal 1 Maret 2020. 
dalam perjanjian pendahuluan jual beli atau perjanjian pengikatan jual beli sebelum ditandatangani akta jual beli.

AJB belum dapat dilaksanakan, karena adanya persyaratan yang belum terpenuhi atau belum diselesaikan. PPJB sangat menguntungkan bagi para pengembang apartemen, karena pengembang tetap dapat melakukan pemasaran dan penjualan meskipun pembangunan apartemen belum selesai dibangun atau pecah sertifikat belum selesai atau masih dalam tahap pengurusan.

PPJB disebut juga sebagai Perjanjian Inoominaat atau perjanjian tidak bernama. Perjanjian tidak bernama diatur dalam Dalam Pasal 1319 Kitab UndangUndang Hukum Perdata. Kitab Undang-Undang Hukum Perdata tidak mengatur mengenai PPJB, namun buku III KUHPerdata yang bersifat terbuka dapat dijadikan dasar dalam pembuatan PPJB, berdasarkan Pasal 1319 KUHPerdata : "Semua perjanjian baik yang mempunyai suatu nama khusus, maupun yang tidak terkenal dengan suatu nama tertentu, tunduk pada peraturan-peraturan umum yang termuat dalam bab ini dan bab yang lalu”. Meskipun, PPJB merupakan perjanjian tidak bernama yang tidak diatur dalam KUHPerdata seperti perjanjian jual beli dan sewa menyewa, namun masuk dalam ruang lingkup Perjanjian pada buku ke III tentang Perikatan (Hukum Perikatan)

Sistem terbuka pada Buku III KUHPerdata, memungkinkan para pihak membuat suatu perjanjian sesuai dengan kehendaknya yang lebih dikenal dengan asas kebebasan berkontrak. Asas kebebasan berkontrak, terdapat dalam Pasal 1338 ayat 1 KUHPerdata, bahwa : "Semua persetujuan yang dibuat secara sah berlaku sebagai Undang-Undang bagi mereka yang membuatnnya." Azas Kebebasan Berkontrak berarti perjanjian dalam bentuk apapun yang dibuat oleh para pihak secara sah sepanjang tidak bertentangan dengan undang-undang yang berlaku, kesusilaan dan kepentingan umum mengikat para pihak yang menyetujuinya.

PPJB sebagaimana halnya perjanjian pada umumnya, harus memenuhi syarat perjanjian dalam Pasal 1320 KUHPerdata agar perjanjian tersebut dianggap sah. Syarat sah perjanjian yang harus dipenuhi dalam Pasal 1320 KUHPerdata yaitu :

1. Sepakat ; 
2. Cakap ;

3. Suatu hal tertentu dan ;

4. Sebab yang halal.

Berdasarkan ketentuan Pasal 2 angka 2 PERMEN PUPR No.11/PRT/M/2019, PPJB harus dinyatakan dalam bentuk Akta Notaris. PPJB yang dibuat antara developer dan calon pembeli akan menimbulkan hak dan kewajiban bagi pihak yang membuatnya tetapi belum ada penyerahan hak milik (SHMSR) yang merupakan objek perjanjian dalam PPJB apartemen ini. Menurut Pasal 1313 KUHPerdata suatu perjanjian adalah suatu perbuatan dengan mana satu orang atau lebih mengikatkan dirinya terhadap satu orang lain atau lebih. PPJB lahir karena adanya kesepakatan yang terlahir dari para pihak yang membuat perjanjian.

Dalam Pasal 43 ayat 1 Undang-Undang Rumah Susun, menyebutkan Proses jual beli sarusun sebelum pembangunan rumah susun selesai dapat dilakukan melalui PPJB yang dibuat dihadapan Notaris. PPJB yang dibuat dan ditandatangani oleh para pihak yaitu calon pembeli dan pengembang merupakan kehendak dari para pihak, meskipun seringkali PPJB dibuat oleh salah satu pihak yaitu pihak pengembang. PPJB dibuat sebagai pengikatan sementara, sebelum AJB resmi dibuat dihadapan PPAT (Pejabat Pembuat Akta Tanah). Di dalam PPJB selain terdapat hak dan kewajiban para pihak, biasanya juga terdapat kalusul, bahwa Akta Jual Beli (AJB) akan ditanda tangani di hadapan PPAT di kemudian hari, setelah semua persyaratan dalam jual beli terpenuhi.

Penandatanganan PPJB oleh para pihak, belum menyebabkan obyek PPJB beralih kepada pembeli meskipun telah dilunasi oleh pihak pembeli. Berdasarkan ketentuan Pasal 1459 KUIHPerdata, bahwa "Hak Milik atas barang yang dijual tidak pindah kepada pembeli selama barang itu belum diserahkan menurut Pasal 612, 613 dan 616". Hubungan hukum para pihak dalam PPJB Apartemen belum berakhir, selama PPJB Apartemen yang dibuat belum berakhir (belum terlaksananya prestasi dalam perjanjian).

\section{Jual Beli Apartemen}


Jual Beli menurut Pasal 1457 KUHPerdata adalah persetujuan dengan mana pihak yang satu mengikatkan dirinya untuk menyerahkan suatu kebendaan dan pihak lain untuk membayar harga yang telah ditetapkan. Dari pasal tersebut, dapat dilihat bahwa unsur esensialia dari perjanjian jual beli adalah adanya kesepakatan mengenai barang dan harga. Berdasarkan ketentuan Pasal 1457 KUHPerdata tersebut, dapat dipahami bahwa perjanjian jual beli apartememen yang akan dilaksanakan antara pengembang dan pembeli merupakan perjanjian yang menimbulkan hak dan kewajiban dimana salah satu pihak (pengembang) menyerahkan apartemen dan pihak lain (pembeli) membayar harga satuan apartemen sesuai kesepakatan dalam perjanjian.

Lebih lanjut dalam Pasal 1458 KUH Perdata mengatur bahwa "Perjanjian jual beli telah dianggap terjadi antara pihak penjual dan pembeli, pada saat terjadinya persesuaian kehendak dan pernyataan antara mereka tentang barang dan harga, meskipun barang itu belum diserahkan maupun harganya belum dibayar lunas."

Perjanjian Jual Beli menurut Kitab Undang-Undang Hukum Perdata belum memindahkan hak milik. Adapun hak milik baru berpindah dengan dilakukannya penyerahan (levering). Dengan demikian penyerahan (levering) merupakan suatu perbuatan hukum guna memindahkan hak milik yang caranya tergantung benda yang dijual. ${ }^{10}$

Prof. Subekti mengemukakan, oleh para sarjana Belanda, levering dikonstruksikan sebagai suatu zakelijke overeenkomst, ialah suatu persetujuan bagi tahap kedua antara penjual dan pembeli yang khusus bertujuan memindahkan hak milik dari penjual kepada pembeli. Dilihat dari jenis barang yang menjadi obyek jual beli maka dapat dibedakan atas barang tidak bergerak, barang bergerak dan barang tak berwujud, oleh karenanya penyerahan (levering) atas masing-masing barang tersebut berbeda. ${ }^{11}$

Apartemen merupakan barang (benda) tidak bergerak yang kepemilikannya dibuktikan melalui SHMSRS, sehingga AJB apartemen harus dilakukan dihadapan PPAT, sebagaimana kewenangan PPAT dalam Pasal 2 ayat 1 Peraturan Pemerintah Nomor 24 Tahun 2016 tentang Perubahan atas Peraturan

\footnotetext{
${ }^{10}$ R. Setiawan, Pokok-Pokok Hukum Perikatan (Bandung : Binacipta, 1987), hal. 23.
}

${ }^{11}$ R. Subekti, Hukum Perjanjian, (Jakarta : Intermassa, 1990), hal. 36. 
Pemerintah Nomor 37 Tahun 1998 tentang Peraturan Jabatan Pejabat Pembuat Akta Tanah, yaitu bertugas pokok melaksanakan sebagian kegiatan pendaftaran tanah dengan membuat akta sebagai bukti telah dilakukannya perbuatan hukum tertentu mengenai hak atas tanah atau Hak Milik Atas Satuan Rumah Susun, yang akan dijadikan dasar bagi pendaftaran perubahan data pendaftaran tanah yang diakibatkan oleh perbuatan hukum itu.

Akta yang dibuat oleh PPAT sebagai bukti telah dilakukannya perbuatan hukum tertentu mengenai hak atas tanah atau Hak Milik Atas Satuan Rumah Susun dapat dijadikan dasar perlaihan hak atas tanah dan bangunan untuk balik nama di BPN. ${ }^{12}$ Hal ini sesuai dengan Pasal 44 ayat 1 Undang-Undang Rumah Susun disebutkan bahwa proses jual beli, yang dilakukan sesudah pembangunan rumah susun selesai, dilakukan melalui Akta Jual Beli (AJB).

\section{Peralihan Hak Milik Apartemen atas dasar PPJB}

Hak Milik berdasarkan Pasal 584 yaitu Hak milik atas sesuatu kebendaan tak dapat diperoleh dengan cara lain, melainkan dengan pemilikan, karena pelekatan, karena daluarsa, karena pewarisan, baik menurut Undang- Undang maupun surat wasiat dan karena penunjukan atau penyerahan berdasar atas suatu peristiwa perdata untuk memindahkan hak milik, dilakukan oleh seorang yang berhak berbuat bebas terhadap kebendaan itu." Berdasarkan Pasal 584 KUHPerdata tersebut, cara memperoleh hak milik dapat dilakukan melalui :

1. Pemilikan.

2. Pelekatan.

3. Daluarsa.

4. Pewarisan.

Hak Milik atas Satuan Rumah Susun merupakan Hak Milik yang termasuk benda tidak bergerak, sehingga merujuk pada ketentuan Pasal 616 KUH Perdata, bahwa penyerahan benda tidak bergerak dilakukan melalui pengumuman akta yang bersangkutan dengan cara seperti ditentukan dalam Pasal 620 KUHPerdata yaitu pengumuman yang dimaksud dengan memindahkan salinan akta 
otentik dari akta tersebut dan mendaftarkan dalam daftar yang ditentukan. Hal ini dilakukan dengan mendaftarkan (balik nama) Akta Jual Beli Apartemen sebagai dasar peralihan hak dari penjual kepada pembeli ke Kantor BPN Kota/Kabupaten dimana Apartemen yang menjadi objek jual beli berada.

Dengan berlakunya UUPA, pendaftaran hak atas tanah termasuk Hak Milik atas Satuan Rumah Susun (HMSRS) sebagai bukti kepemilikan apartemen peralihan haknya dilakukan berdasarkan ketentuan Pasal 19 UUPA dan peraturan pelaksananya. Dengan kata lain HMSRS salah satu penyerahannya dapat dilakukan dengan penyerahan berdasarkan suatu peristiwa perdata yaitu jual beli.

Dengan adanya AJB apartemen, beralihnya HMSRS ketika nama penjual diubah menjadi nama pembeli yang didaftarkan oleh PPAT di BPN, hal ini sebagaimana bunyi Pasal 2 ayat 1 Peraturan Pemerintah Nomor 24 Tahun 2016 tentang Perubahan atas Peraturan Pemerintah Nomor 37 Tahun 1998 tentang Peraturan Jabatan PPAT, bahwa "PPAT bertugas pokok melaksanakan sebagian kegiatan pendaftaran tanah dengan membuat akta sebagai bukti telah dilakukannya perbuatan hukum tertentu mengenai hak atas tanah atau Hak Milik Atas Satuan Rumah Susun, yang akan dijadikan dasar bagi pendaftaran perubahan data pendaftaran tanah yang diakibatkan oleh perbuatan hukum itu."

Umumnya PPJB yang dilakukan dalam perikatan pembelian apartemen dilakukan karena unit apartemen belum jadi dan masih dalam tahap perencanaan. Selain itu, sertifikat hak miik atas satuan rumah susun yang belum pecah dari sertifikat induknya, juga menjadi faktor penghambat dilaksanakannya AJB. Lamanya tenggang waktu jual beli apartemen antara PPJB dan AJB, terkadang menimbulkan realita baru yang berkembang di masyarakat. Salah satunya adalah pengalihan unit apartemen tersebut kepada pihak ketiga oleh pembeli yang membutuhkan uang .

Jika merujuk pada ketentuan-ketentuan dalam Pasal 616 dan 620 KUHPerdata tersebut, PPJB belum memindahkan HMSRS tersebut, karena belum adanya perpindahan (penyerahan) hak milik yang harus dilakukan dengan akta otentik yang dibuat di hadapan PPAT yaitu AJB. Bahkan AJB pun belum dikatakan memindahkan HMSRS jika belum dilakukan pendaftaran balik nama dari penjual kepada pembeli di BPN Kota/Kabupaten setempat. Maka, sudah 
seharusnya peralihan hak kepada pihak ketiga dari pembeli apartemen atas dasar PPJB yang dimiliki tidak dapat dilakukan, karena .belum adanya penyerahan hak (HMSRS) dari penjual apartemen.

Namun, berdasarkan Surat Edaran Mahkamah Agung (SEMA) Nomor 4 Tahun 2016 tentang Pemberlakuan Rumusan Hasil Rapat Pleno Kamar Mahkamah Agung Tahun 2016, disebutkan bahwa "Peralihan hak atas tanah berdasarkan Perjanjian Pengikatan Jual Beli (PPJB) secara hukum terjadi jika pembeli telah membayar lunas harga tanah serta telah menguasai objek jual beli dan dilakukan dengan itikad baik.” Berdasarlan SEMA Nomor 4 Tahun 2016 tersebut, dapat diartikan bahwa terhadap PPJB apartemen yang telah dibayar dengan lunas oleh pembeli dan objeknya telah dikuasai dengan itikad yang baik, maka secara hukum hak atas tanah (HMSRS) telah beralih. Oleh karena itu, jika terjadi peralihan HMSRS unit apartemen yang telah selesai dan dikuasai pembeli dengan itikad baik atas dasar PPJB, meskipun sertifikat belum pecah dapat dialihkan kepada pihak ketiga. Ketentuan ini tidak beraku untuk PPJB yang dilakukan dengan cara mencicil, PPJB lunas yang Apartemennya belum selesai di bangun (belum dikuasai pembeli) dan PPJB yang dilakukan dengan menguasai Apartemen (objek PPJB) tidak dengan itikad baik.

\section{E. Jual Beli Apartemen atas dasar PPJB Kepada Pihak Ketiga melalui Perjanjian Pengalihan Hak}

Berdasarkan Surat Edaran Mahkamah Agung (SEMA) Nomor 4 Tahun 2016 tentang Pemberlakuan Rumusan Hasil Rapat Pleno Kamar Mahkamah Agung Tahun 2016, disebutkan bahwa hanya Apartemen yang telah dibayar lunas dan telah dikuasai oleh pembeli dengan itikad baiklah yang telah beralih haknya (HMSRS) dari penjual kepada pembeli, meskipun AJB belum terjadi di hadapan PPAT dan belum terlaksananya balik nama di BPN.

Ketentuan ini tidak beraku untuk PPJB yang dilakukan dengan cara mencicil, PPJB lunas yang Apartemennya belum selesai di bangun (belum dikuasai pembeli) dan PPJB yang dilakukan dengan menguasai Apartemen (objek PPJB) tidak dengan itikad baik. Oleh karena itu, pihak pembeli atas dasara PPJB yang dimiliki yang membutuhkan uang, telah dapat mengalihkan 
haknya kepada pihak ketiga. Namun dalam prakteknya, masih banyaknya peralihan hak atas unit apartemen yang dilakukan oleh masayarakat, meskipun pembayaran PPJB belum lunas dan objek PPJB (Apartemen) belum dikuasai dengan itikad baik.

Perjanjian pengalihan unit apartemen kepada pihak ketiga oleh pembeli atas dasar PPJB yang dimiliki dapat dilakukan dengan membuat Perjanjian Pengalihan Hak. Dalam Perjanjian Pengalihan Hak, terdapat pengalihan hak dan kewajiban atas apartemen yang dilakukan pihak pembeli (lama) kepada pihak ketiga (mengalihkan PPJB yang dibuat antara pembeli dengan pengembang yang dibuat sebelumnya). Selanjutnya, pihak ketiga (pembeli baru) yang akan menandatangani Akta Jual Beli (AJB) dengan pihak pengembang atas dasar Perjanjian Pengalihan Hak tersebut.

Sebelum pihak pembeli (lama) melakukan perjanjian pengalihan hak dengan pihak ketiga (pembeli baru) atas dasar PPJB, maka harus diperhatikan, terdapat atau tidaknya klausul (persyaratan dan ketentuan) yang mengatur peralihan hak apartemen kepada pihak ketiga. Selain itu, perlu dilakukan pemberitahuan kepada pengembang dan persetujuan pengembang apartemen untuk melakukan Perjanjian Pengalihan Hak kepada pihak ketiga. Hal ini dikarenakan, PPJB yang dibuat oleh para pihak hanya mengikat pihak yang membuatnya.

Perjanjian Pengalihan Hak biasanya dibuat dengan dua cara, yaitu melalui akta otentik yang dibuat dihadapan pejabat yang berwenang (Notaris) dan melalui perjanjian di bawah tangan. Umumya, Perjanjian Pengalihan Hak dilakukan melalui akta otentik yang dibuat dihadapan Notaris. Hal ini dikarenakan bahwa akta sebagaimana akta yang mempunyai kekuatan pembuktian adalah Akta Notaris, yaitu akta otentik yang memiliki kekuatan hukum dengan jaminan kepastian hukum sebagai alat bukti tulisan yang sempurna (volledig bewijs) tidak memerlukan tambahan alat pembuktian lain dan hakim terikat karenanya. ${ }^{13}$ Akta yang dibuat Notaris memiliki kekuatan pembuktian yang sempurna dibandingkan akta dibawah tangan yang dibuat sendiri oleh para pihak yang berkepentingan tanpa adanya bantuan pejabat umum.

${ }^{13}$ A.A.Andi Prajidno, Apa dan Siapa Notaris di Indonesia?, Cetakan Pertama, (Surabaya : Putra Media Nusantara, 2010), hal.51. 
Sebelum melakukan Perjanjian Pengalihan Hak, pihak ketiga melakukan pembayaran yang jumlahnya telah terlebih dahulu disepakati dengan Pihak Pembeli (lama) atas objek perjanjian yang dialihkan yaitu unit apartemen yang menjadi obyek PPJB sebagaimana jual beli pada biasanya. Dengan ditandatanganinya Perjanjian Pengalihan Hak, menyebabkan hak dan kewajiban Pembeli (lama) beralih ke pihak ketiga (pembeli baru). Hal ini menyebabkan pihak ketiga (pembeli baru) akan menggantikan posisi pembeli (lama) dalam Perjanjian PPJB yang sebelumnya dibuat dan menandatangani AJB yang akan dibuat di kemudian hari setelah semua persyaratan selesai.

Setelah semua persyaratan selesai, Pihak Ketiga (Pembeli Baru) dan Pengembang sebagai penjual akan menandatangani Akta Jual Beli dihadapan PPAT, dan PPAT akan mendaftarakan proses balik nama AJB tersebut ke BPN Kota/Kabupaten setempat. Nama pembeli (pihak ketiga) yang akan dimasukkan sebagai nama pemegang SHMSRS (Sertifikat Hak Milik Satuan Rumah Susun).

\section{PENUTUP}

\section{Kesimpulan}

1. Berdasarkan Surat Edaran Mahkamah Agung (SEMA) Nomor 4 Tahun 2016 tentang Pemberlakuan Rumusan Hasil Rapat Pleno Kamar Mahkamah Agung Tahun 2016, terhadap PPJB apartemen yang telah dibayar dengan lunas oleh pembeli dan objeknya telah dikuasai dengan itikad yang baik, maka secara hukum hak atas tanah (HMSRS) telah beralih. Oleh karena itu, jika terjadi peralihan HMSRS unit apartemen yang telah selesai dan dikuasai pembeli dengan itikad baik atas dasar PPJB, meskipun sertifikat belum pecah dapat dialihkan kepada pihak ketiga. Ketentuan ini tidak beraku untuk PPJB yang dilakukan dengan cara mencicil, PPJB lunas yang Apartemennya belum selesai di bangun (belum dikuasai pembeli) dan PPJB yang dilakukan dengan menguasai Apartemen (objek PPJB) tidak dengan itikad baik.

2. Bentuk pengalihan hak yang dilakukan oleh pembeli apartemen kepada pihak ketiga atas dasar PPJB dapat dilakukan melalui Perjanjian Pengalihan Hak. Dengan ditandatanganinya Perjanjian Pengalihan Hak, menyebabkan hak dan kewajiban Pembeli (lama) beralih ke pihak ketiga (pembeli baru). Hal ini 
menyebabkan pihak ketiga (pembeli baru) akan menggantikan posisi pembeli (lama) dalam Perjanjian PPJB yang sebelumnya dibuat dan menandatangani AJB yang akan dibuat di kemudian hari setelah semua persyaratan selesai.

\section{DAFTAR PUSTAKA}

\section{Buku}

Hutagalung, Arie S. Kondominium dan Permasalahannya, Jakarta : Badan Penerbit Fakultas Hukum Universitas Indonesia, 2007.

Prajidno, A.A.Andi. Apa dan Siapa Notaris di Indonesia ?, Cetakan Pertama, Surabaya : Putra Media Nusantara, 2010

Setiawan, R. Pokok-Pokok Hukum Perikatan, Bandung, Binacipta, 1987. 2006

Soekanto, Soerjono. Pengantar Penelitian Hukum, Jakarta : UI Press,

Subekti, R. Hukum Perjanjian, Jakarta : Intermassa, 1990.

Sutedi, Adrian. Hukum Rumah Susun \& Apartemen, Jakarta, Sinar Grafika, 2013.

\section{Artikel}

Pandam Nurwulan, "Aspek Hukum Transaksi Jual Beli Rumah Susun/Apartemen di Daerah Istimewa Yogyakarta Kaitannya dengan Peran Notaris-PPAT", Jurnal Hukum Ius Quia Iustum, Volume 22 Nomor 4, Oktober 2015.

\section{Peraturan}

Indonesia, Kitab Undang-Undang Hukum Perdata.

Indonesia, Undang-Undang Nomor 20 Tahun 2011 tentang Rumah Susun.

Indonesia, Peraturan Pemerintah Nomor 24 Tahun 1997 Tentang Pendaftaran Tanah.

Indonesia, Peraturan Pemerintah Nomor 24 Tahun 2016 tentang Perubahan atas Peraturan Pemerintah Nomor 37 Tahun 1998 tentang Peraturan Jabatan Pejabat Pembuat Akta Tanah.

Indonesia, Peraturan Menteri Pekerjaan Umum dan Perumahan Rakyat Nomor 11/PRT/M/2019 tentang Sistem Perjanjian Pendahuluan Jual Beli Rumah.

\section{Internet}


Shanti Rachmadsyah, "PPJB Tentang Rusunami", https://www.hukumonline.com/klinik/detail/ulasan/lt4c5ba2076b60d/ppjbtentang-rusunami/, diakses tanggal 1 Maret 2020. 